\title{
Рецензія на: Грищенко Ю. Болгари в Україні 1920-х-1930-х рр.: між національними проектами влади й реаліями життя. Київ, Інститут історії України НАН України, 2018. 269 с.
}

\author{
В. В. Турков
}

Опублікована 2018 р. монографія Юлії Грищенко є першим в українській історіографії комплексним дослідженням історії болгарської національної меншини України у 20-30-ті pp. XX ст. Для написання роботи авторка використала чисельні документи Центрального державного архіву вищих органів влади та управління України, Центрального державного архіву громадських об'єднань України, державних архівів Запорізької, Кіровоградської, Миколаївської, Одеської областей, Архіву тимчасового зберігання управління Служби Безпеки України у Харківській області, архівів управління Служби Безпеки України в Запорізькій та Одеській областях. Значна частина архівних документів введена в науковий обіг вперше.

Монографія відзначається чіткою та логічною структурою. У вступі Ю. Грищенко детально проаналізувала історіографію та джерельну базу дослідження. Перший розділ роботи розкриває політичні аспекти формування болгарської етнічної спільноти, зокрема висвітлюються етапи, особливості та наслідки переселенської політики Російської імперії, яка привела до появи на території Півдня України та Криму багатьох болгарських поселень. Ю. Грищенко розкриває соціально-економічне становище болгарського населення у період проведення Столипінської аграрної реформи та у часи Першої світової війни. Водночас авторка зупиняється на участі болгар у збройній боротьбі на боці повстанських формувань під керівництвом Нестора Махна в Приазов'ї. Не залишилося поза увагою й боротьба болгарського населення Одещини проти регулярних військ армії Денікіна в роки громадянської війни.

У першому розділі Ю. Грищенко зупинилася також на детальному аналізі діяльності радянських органів з етнополітичного врегулювання, які на практиці займалися вирішенням соціально-економічних та культурно-освітніх проблем національних меншин України, у тому числі болгар, як на союзному, так і на республіканському рівнях, починаючи від Наркомнацу на чолі з Й. Сталіним і закінчуючи Центральною комісією у справах національних меншин при ВУЦВК. Всебічно розкриті питання, пов'язані з проведенням адміністративно-територіального будівництва в місцях компактного проживання болгар, яке привело до створення болгарських національних районів, селищних рад, органів влади, міліції та суду.

У другому розділі монографії вдалою є спроба Ю. Грищенко дослідити соціально-економічне становище болгарського населення УСРР у часи проведення нової економічної політики та суцільної колективізації. Чітко визначаються причини, масштаби та демографічні наслідки голодоморів 1921-1922 та 1932-1933рр., що не оминули й болгарську спільноту України.

Значне місце в роботі відведено висвітленню історії створення системи культурноосвітніх установ, видавництв і болгаромовної преси, а, з іншого боку, - згортанню політики коренізації, що у подальшому привело до реорганізації освітніх закладів з болгарською мовою викладання, ліквідації освітніх установ і національних районів.

В заключному розділі монографії авторка розкриває завдання, цілі та особливості проведення «Болгарської національної операції» доби Великого терору. Наводяться цікаві статистичні дані, які дозволяють оцінити масштаби репресій не тільки щодо болгар, але i до представників інших етнічних груп. Розкриваються й трагічні сторінки біографії окремих болгар, що стали жертвами політичних репресій наприкінці 30-х рр. XX ст. Мова йде про представників партійно-державного апарату республіки, редакторів газет й інших посадовців, які працювали у різних галузях народного господарства, діячів культури і освіти та звичайних робітників і колгоспників. 
Відзначаючи велику наукову цінність рецензованої праці, вкажемо й на деякі іï недоліки. Так, при висвітленні історіографії, варто було згадати дисертацію В. В. Туркова ${ }^{1}$ та численні праці М. Г. Станчева ${ }^{2}$ У У першому розділі роботи, авторка не розкрила особливості впровадження більшовиками політики воєнного комунізму, яка, з ії продрозверсткою та забороною приватної торгівлі, стала головною причиною повстанського руху болгар на Одещині. У другому розділі монографії, аналізуючи реалізації владою нової економічної політики, Ю. Грищенко не приділила належної уваги економічній діяльності артілей болгар-городників, які займалися виробництвом сільськогосподарської продукції біля Харкова, Одеси, Мелітополя та промислових міст Донбасу, забезпечуючи населення городиною. У третьому розділі роботи при висвітленні теми суцільної колективізації сільського господарства не було розкрито механізм депортації, коли заможні болгарські родини та інші «політично шкідливі елементи» збиралися співробітниками НКВС на заздалегідь визначених станціях та ешелонами відправлялися у північні та східні райони СРСР. У цьому ж контексті варто було б зосередити увагу на суперечливій постаті Х. Г. Раковського, який у 1919-1923 рр. очолював уряд УСРР, а отже ніс відповідальність за встановлення та зміцнення більшовицької влади в Україні, працюючи згодом на відповідальних дипломатичних посадах у Великій Британії та Франції. Як відомо, 1937 р. Х. Г. Раковський, що перейшов у опозицію до Сталіна, був заарештований у справі «Антирадянського правотроцькистського блоку», у 1938 р. засуджений до двадцяти років тюремного ув'язнення й через три роки розстріляний. Аналізуючи репресії проти болгарської національної меншини, необхідно було також згадати й долю болгар-політемігрантів, які працювали у комуні імені Благоєва на Полтавщині, що теж стали жертвами політичних репресій наприкінці $30-\mathrm{x} \mathrm{pp.} \mathrm{XX} \mathrm{ст.}{ }^{3}$

Проте, вказані недоліки не знижують високу наукову цінність роботи, яка є важливим внеском у розвиток сучасної української болгаристики.

${ }^{1}$ Турков В. В. Політика Росії щодо переселення та влаштування бессарабських болгар на південноукраїнських землях 1856-1871 рр.: дис. канд. іст. наук. Харків, 1997. 168 с.

${ }^{2}$ Станчев М. Болгары в Российской империи, СССР, странах Балтии и СНГ. Том 1 (1711-2006). Статистический сборник. София: Академическое из-во имени проф. Марина Дринова, 2009. 619 с. Його ж. Болгары в Российской империи, СССР, странах Балтии и СНГ. Том 2: Биографическая энциклопедия. Харьков: ИПП «Контраст», 2016. 592 с. Його ж. Д-р Кръстьо Раковский - държавник, политик, дипломат / Превод от руски Лазар Георгиев. София: Академично издателство „Марин Дринов“, 2004. 314 с. Його ж. «Дело 13-ти» (о процессе 1937-1938 гг. над так называемой «Болгарской контрреволюционной националистической организацией в Украине») // Дриновський збірник / Дриновски зборник T. VI. Харків-Софія: Академічне видавництво «Проф. Марин Дринов», 2013. С. 368-412. Його ж. «Дело 13-ти» (о процессе над так называемой «Болгарской контрреволюционной националистической организацией» в Украине 1937-1938 гг.). Продолжение // Дриновський збірник / Дриновски зборник T. VII. Харків-Софія: Академічне видавництво «Проф. Марин Дринов», 2014. С. 357-392. Його ж. «Дело 13-ти» (о процессе над т. н. «Болгарской контрреволюционной националистической организацией» в Украине 1937-1938 гг.). Продолжение // Дриновський збірник / Дриновски зборник Т. VIII. Харків-Софія: Академічне видавництво «Проф. Марин Дринов», 2015. С. 383-414. Його ж. «Дело 13-ти» (о процессе 1937-1938 гг. над так называемой «Болгарской контрреволюционной националистической организацией в Украине»). Дриновський збірник / Дриновски зборник Т. IX. Харків-Софія: Академічне видавництво «Проф. Марин Дринов», 2016. C. $413-439$.

${ }^{3}$ Єрмак О. Доля болгарських комуністів // 3 архівів ВУЧК - ГПУ - НКВД - КГБ. 1994. № 1. C. $59-63$. 